\title{
Tussilago Farfara Extract (TFE) as Green Corrosion Inhibitor for Aluminum in Hydrochloric Acid Solution
}

\author{
Abd El-Aziz S. Fouda 1,*(D), Eslam Abdel Haleem ${ }^{1,2}$ \\ 1 Department of Chemistry, Faculty of Science, El-Mansoura University, Egypt \\ 2 Department of Basic Science, Higher Institute of Engineering and Technology in El-Arish, Egypt \\ * Correspondence: easfouda@ hotmail.com;
}

Scopus Author ID 56231506400

Received: 27.03.2020; Revised: 18.05.2020; Accepted: 20.05.2020; Published: 1.06.2020

\begin{abstract}
The dissolution of aluminum in $2 \mathrm{M} \mathrm{HCl}$ medium in the absence and presence of Tussilago Farfara Extract (TFE) was examined utilizing Tafel polarization (TP), electrochemical impedance spectroscopy (EIS), electrochemical frequency modulation (EFM), gasometry and mass reduction techniques. The outcomes of these procedures illustrated that the inhibiting effect of this inhibitor depends on its concentration and chemical composition. The inhibitive impact of TFE illustrated the blocking of the $\mathrm{Al}$ surface by adsorption of its components through the reacted atoms contained in its molecules. The adsorption model was obeyed to Langmuir isotherm. The influence of temperature on the dissolution rate in the non-existence and existence of TFE was observed. Tafel polarization indicated that TFE acts as a mixed kind inhibitor. Impedance outcomes illustrated that the dissolution of $\mathrm{Al}$ is monitored by charge transfer mode at all concentrations of the extract. Varied surface examinations like XPS, FTIR, and AFM were checked to affirm the presence of the defensive film on the Al surface. All outcomes measured from all procedures are in perfect conformity.
\end{abstract}

Keywords: Tussilago Farfara Extract (TFE); TP; AFM; XPS; Langmuir isotherm.

(C) 2020 by the authors. This article is an open-access article distributed under the terms and conditions of the Creative Commons Attribution (CC BY) license (https://creativecommons.org/licenses/by/4.0/).

\section{Introduction}

Aluminum and its alloys are utilized for several purposes due to its low price, little weight, and thermal conductivity. $\mathrm{HCl}$ medium is applied for electrochemical etching of $\mathrm{Al}$ samples and printed plates. It is more significant to utilize dissolution inhibitors to diminish the dissolution of $\mathrm{Al}$ in any destructive medium. Organic amines like nitrogen heterocyclic particles were experimented as dissolution retardants [1-10] for Al in destructive media. Ordinarily, it has been presumed that the important step in the mode of the inhibitors in destructive media is the adsorption of these inhibitors onto the outer surface. Eco-friendly extracts turned into beneficial retardants because they are green inhibitor, cheap, and naturally available. These retardants are found to contain varied organic compositions which naturally synthesized and can be extracted by necessary procedures with minimal effort. These products were lately utilized as dissolution retardants for varied metals in changed cases [11-23], and their concentrations were computed. The acquired estimations illustrated that plant extract could fill in as effective dissolution retardants. The target of this research is to check the inhibitive influence of Tussilago Farfara extract (TFE) in $2 \mathrm{M} \mathrm{HCl}$ media to estimate its inhibition proficiency. Weight reduction, $\mathrm{H}_{2}$ release, Tafel polarization, electrochemical impedance spectroscopy, and electrochemical frequency modulation were applied to measure the inhibition proficiency of Tussilago Farfara extract. 


\section{Materials and Methods}

\subsection{Composition of Aluminum pieces.}

$\mathrm{Al}$ pieces checked in this investigation were taken from $\mathrm{Al}$ with the purification of 99.98 $\%$.The pieces with measures $2 \times 2 \times 0.5 \mathrm{~cm}$.

\subsection{Solutions and Materials}

All techniques were applied to utilize $\mathrm{Al}$ foils $1 \mathrm{~cm}^{2}$ as a working electrode; an epoxy gum occupied the volume between Teflon and $\mathrm{Al}$ cathode. The auxiliary anode was a platinum sheet $\left(1 \mathrm{~cm}^{2}\right)$, reference electrode represents as saturated calomel cathode (SCE) was linked to electrolytic cell utilizing a bridge with a Luggin fine. The end was near the outer part of the working electrode to promote the IR drop. The destructive medium was set up by dilution of $34 \% \mathrm{HCl}$ with bi-distilled $\mathrm{H}_{2} \mathrm{O}$. The stock medium (1000 ppm) of (TFE) was utilized to obtain the varying amounts by the addition of bi-distilled $\mathrm{H}_{2} \mathrm{O}$. The concentration extent was (50-300) ppm. The main chemical compositions of (TFE) are caffeoylquinate, Hyperoside, Kaempferol, Quercetin and Rutin [24, 25].

\subsection{Plant extract.}

The leaves were left for 10-15 days till dryness at $30 \mathrm{C}^{\circ}$ and turned to fine powder utilizing an electrical blender instrument. Two hundred grams were dissolved in methanol $70 \%$ for $48 \mathrm{~h}$. The residual part was isolated by filter papers. The dissolvable was extracted entirely under a rotational vacuum. The dried residues were immersed in $3 \mathrm{ml}$ of Dimethyl sulfoxide (DMSO) and completed to 1 liter, utilized ethanol, and at last, stocked under refrigeration in enclosed flasks. Figure 1 shows the image of the plant, and Table 1 shows the chemical components that exist in Tussilago Farfara extract.
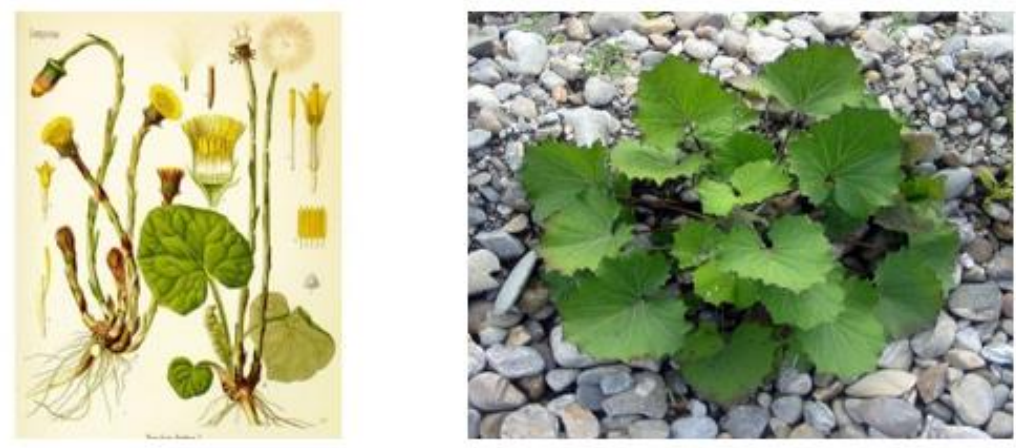

Figure 1. Foliage of Tussilago Farfara.

Where $i_{\text {corr(inh) }}$ and $i_{\text {corr }}$ are the inhibited and uninhibited currents.

\subsection{Procedures utilized for dissolution estimations.}

2.4.1. Tafel polarization.

Tafel polarization setting was applied in a cell of three electrodes. The platinum sheet is represented as the auxiliary electrode $\left(1 \mathrm{~cm}^{2}\right)$ and a saturated calomel electrode (SCE) as a reference electrode. The anode has appeared as a square foil from $\mathrm{Al}$ of an identical framework implanted in the epoxy coat of polytetrafluorethylene until the area is about $1 \mathrm{~cm}^{2}$. 
Table 1. The chemical components exist in Tussilago Farfara extract.

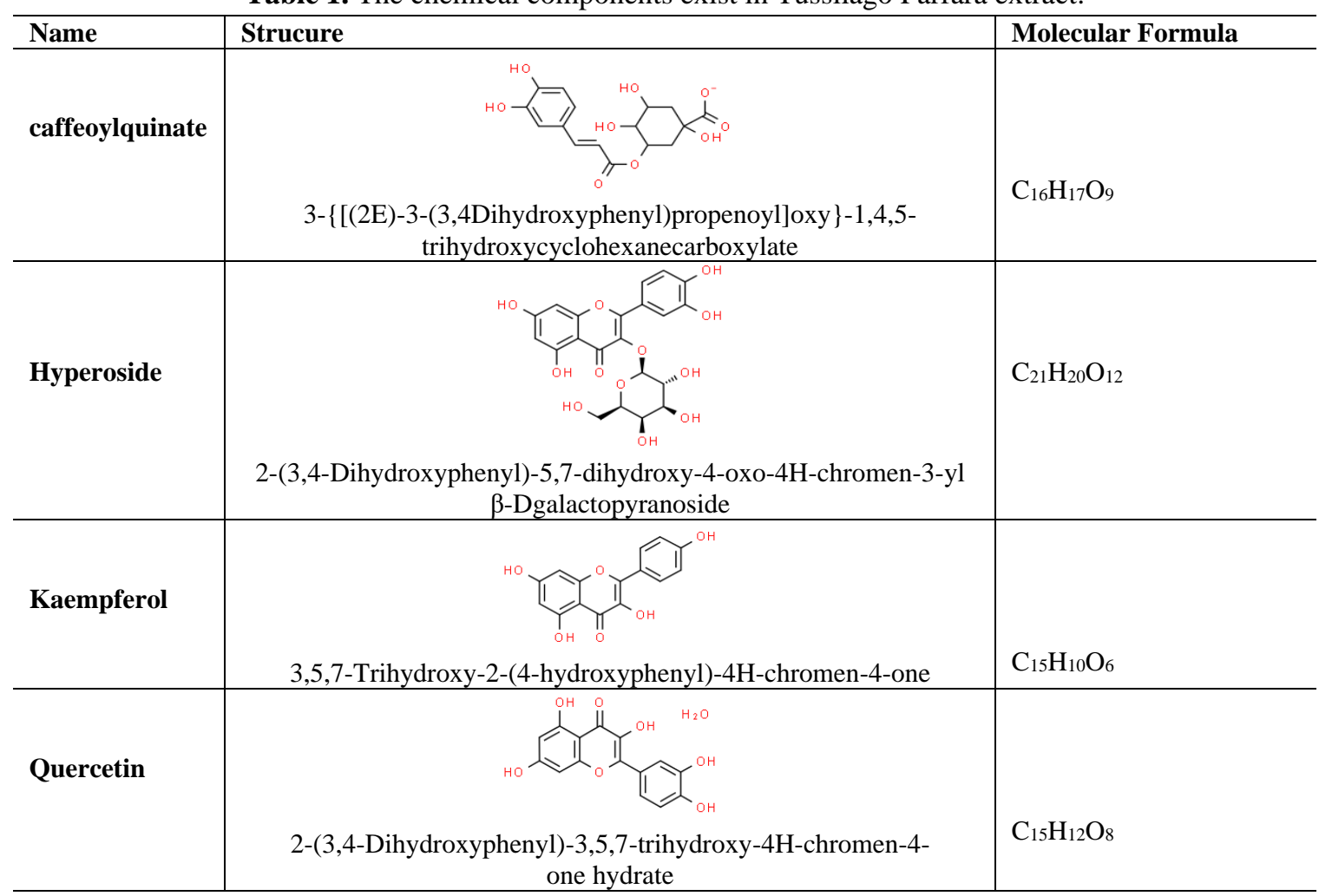

Before tests, the electrodes were dipped in a medium at changed potential (- 600 to $+400 \mathrm{mV}$ ) for half-hour untill attain the steady-state. The trials were applied in the varied amounts at $25^{\circ} \mathrm{C}$. The grade of surface covering $(\theta)$ and $\%$ IE were computed from eq. (1):

$$
\% \text { IE }=\theta \times 100=\left[\left(i_{\text {corr }}-i_{\text {corr }(i n h)}\right) / i_{\text {corr }}\right] \times 100
$$

2.4.2. Electrochemical impedance spectroscopy (EIS).

The impedance examination was applied and discussed, relying on the equivalent loop. The essential parameters gotten from the experiment of the Nyquist graph are the charge transfer resistance $\left(R_{c t}\right)$, polarization resistance $\left(R_{p}\right)$ and the capacitance of double layer $C_{d l}$ [26] that is described as:

$$
\mathrm{C}_{\mathrm{dl}}=1 /\left(2 \pi \boldsymbol{f}_{\max } \mathrm{RP}\right)
$$

Where $\boldsymbol{f}_{\max }$ is the angular frequency. \%IE gotten from the calculations is discussed by the next relationship:

$$
\mathrm{C}_{\mathrm{dl}}=1 /\left(2 \pi \boldsymbol{f}_{\max } \mathrm{RP}\right)
$$

$$
\% \mathrm{IE}=\left[1-\left(\mathrm{R}^{\circ} \mathrm{P} / \mathrm{RP}\right)\right] \times 100
$$

Where $\mathrm{R}_{\mathrm{p}}^{\mathrm{o}}$ and $\mathrm{R}_{\mathrm{p}}$ are the polarization resistance in the non-existence and existence of the inhibitor, respectively.

\subsubsection{Electrochemical frequency modulation (EFM).}

EFM technique was performed utilizing two frequencies, 2 and $5 \mathrm{~Hz}$. The standard frequency is $0.1 \mathrm{~Hz}$. Thus the wave renews every $1 \mathrm{sec}$. The spectrum consists of current responses specified for coordinated and intermodulation flow tops. The major max peak was 
performed to compute the current of dissolution ( $\mathrm{i}_{\text {corr }}$ ), the causality variables (CF2 and CF3), and the Tafel slopes $\left(\beta_{\mathrm{a}}\right.$ and $\left.\beta_{\mathrm{c}}\right)[27,28]$.

\subsubsection{Gasometry.}

The emission of $\mathrm{H}_{2}$ is a beneficial procedure that determines the volume of $\mathrm{H}_{2}$ emitted during a dissolution process. The examined vessel must approach through a plastic cylinder to a burette. Firstly, the air quantity was computed. Lastly, Al foils were dipped in the destructive medium, and the experimental vessel was tightly closed. The volume of $\mathrm{H}_{2}$ was rated by the diminishing of the solution grade in the burette at fixed time interims.

\subsubsection{Mass reduction.}

The mass reduction estimations were performed utilizing Al pieces of size $2 \times 2 \times 0.5$ $\mathrm{cm}$. The pieces were firstly scraped to a mirror with $(400,600$, and 1000$)$ coarseness emery sheet, dipped in acetone, washed, get dried before being weighed, and lastly dipped in the destructive medium. All estimations were performed in a $100 \mathrm{ml}$ glass beaker placed in a water thermostat that has $100 \mathrm{ml}$ of $2 \mathrm{M} \mathrm{HCl}$ with an increase of varied amounts of (TFE). After 3 hours of dipping, the samples were removed, washed, dehydrated, and weighed precisely. The mass reduction of all $\mathrm{Al}$ foils could be computed. The degree of surface coverage $(\theta)$ and $\% \mathrm{IE}$ of (TFE) for the dissolution of $\mathrm{Al}$ were measured as follows:

$$
\% \mathrm{IE}=\theta \times 100=\left[\left(\mathrm{W}^{\mathrm{o}}-\mathrm{W}\right) / \mathrm{W}^{\mathrm{o}}\right] \times 100
$$

Where $\mathrm{W}$ and $\mathrm{W}^{\mathrm{o}}$ are the measures of the mass reduction in the existence and absence of the inhibitor, separately.

2.4.8. X-ray photoelectron spectroscopy (XPS).

XPS check provides a profound realization about the idea of the interference among the outer metal surface and the tested retardant.

2.4.7. Fourier-transform infrared spectroscopy (FTIR).

FTIR spectrum was recorded in a PerkinElmer 1600 spectrophotometer. The outer membrane was precisely expelled, mixed perfectly with $\mathrm{KBr}$ formed into a spherule, and the FTIR spectrum was checked.

2.4.6. Atomic force microscopy (AFM).

The main feature of AFM is that the outer surface coarseness can be detected, which is an indication of the outer surface. The surface coarseness is formed due to the distortion of a surface from its exemplary frame.

\section{Results and Discussion}

\subsection{Potentiodynamic polarization.}

The polarization graphs for $\mathrm{Al}$ in destructive mediums at varied concentrations of (TFE) at $25 \pm 1 \mathrm{C}^{\mathrm{o}}$ are observed in Figure 2. The kinetic estimations, for example, dissolution current 
(icorr), dissolution potential ( $\left.E_{c o r r}\right)$, and Tafel slopes $\beta_{a}$ and $\beta_{c}$ measured from the figure are listed in Table 2 for $\mathrm{Al}$ in $2 \mathrm{M} \mathrm{HCl}$ destructive medium in the absence and presence of varying concentrations of (TFE). \%IE rises with increasing the amount of the extract. The addition of the extract shifts the dissolution potentials slightly to increase the extract has an inhibitive influence in both the negative tendency without an apparent change in $\beta_{\mathrm{a}}$ and $\beta_{\mathrm{c}}$ rates. Figure (2) illustrates that the $i_{\text {corr }}$ values diminish by the addition of the extract, which diminishing the Al dissolution. The anodic and cathodic ways of the Tafel curves and the expansion of the extract shifted the $\mathrm{E}_{\text {corr }}$ value to the negative direction compared with the blank Al. Hence, the addition of TFE diminishes the $\mathrm{Al}$ dissolution just as delays the $\mathrm{H}_{2}$ formation response. Equal cathodic Tafel curves in Figure 2 illustrated that the $\mathrm{H}_{2}$ emission and the anodic dissolution of $\mathrm{Al}$ are slightly affected by adding various TFE concentrations based on the experimental information, TFE acts as an inhibitor of mixed type [29].

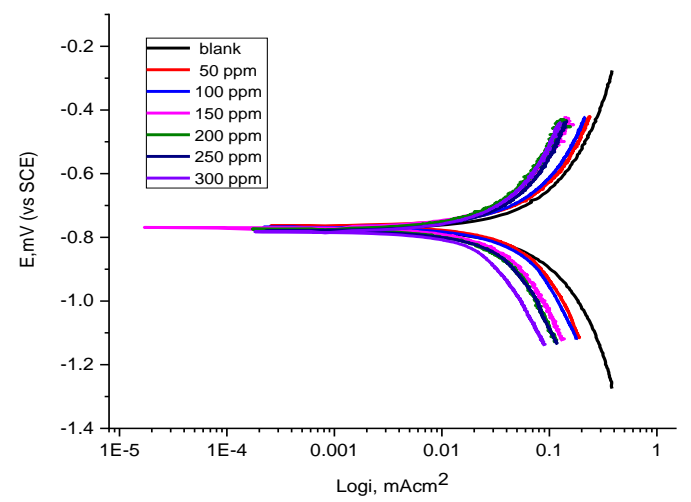

Figure 2. Tafel curves for the dissolution of $\mathrm{Al}$ in $2 \mathrm{M} \mathrm{HCl}$ in the non-existence and existence of varied concentrations of TFE at $25^{\circ} \mathrm{C}$.

Table 2. Results from Tafel curves of $\mathrm{Al}$ in $2 \mathrm{M} \mathrm{HCl}$, including varied concentrations of TFE at $25 \mathrm{C}^{\circ}$.

\begin{tabular}{c|c|c|c|c|c|c|c}
$\begin{array}{c}\text { Conc., } \\
\text { ppm }\end{array}$ & $\begin{array}{c}-E_{\text {corr, }} \mathrm{mV} \\
(\mathrm{vs} \mathrm{SCE})\end{array}$ & $\begin{array}{c}\mathrm{i}_{\text {corr, }} \\
\mathrm{mA} \mathrm{cm}\end{array}$ & $\begin{array}{c}\beta_{\mathrm{a}} \\
\mathrm{mV} \mathrm{dec}^{-1}\end{array}$ & $\begin{array}{c}\beta_{\mathrm{c}} \\
\mathrm{mV} \mathrm{dec}^{-1}\end{array}$ & $\begin{array}{c}\mathrm{C} . \mathrm{R}, \\
\mathrm{mpy}\end{array}$ & $\Theta$ & $\%$ IE \\
\hline Blank & 774.0 & 847 & 765 & 523 & 363.9 & ---- & ---- \\
\hline 50 & 764.2 & 216.0 & 103 & 233 & 92.9 & 0.745 & 74.5 \\
\hline 100 & 768.5 & 161.1 & 112 & 165 & 69.0 & 0.810 & 81.0 \\
\hline 150 & 767.3 & 125.7 & 153 & 205 & 53.9 & 0.852 & 85.2 \\
\hline 200 & 775.7 & 99.8 & 114 & 189 & 42.8 & 0.882 & 88.2 \\
\hline 250 & 773.8 & 85.6 & 125 & 211 & 36.8 & 0.899 & 89.9 \\
\hline 300 & 783.4 & 76.1 & 158 & 198 & 32.7 & 0.911 & 91.1
\end{tabular}

\subsection{Electrochemical impedance spectroscopy (EIS) tests.}

The dissolution behavior of $\mathrm{Al}$ in $2 \mathrm{M} \mathrm{HCl}$ medium with and without varying amounts of (TFE) was examined by EIS procedure at $25 \pm 1 \mathrm{C}^{\mathrm{o}}$ after $30 \mathrm{~min}$ of dipping. Figure 3 demonstrated the Nyquist graph for $\mathrm{Al}$ in $2 \mathrm{M} \mathrm{HCl}$ medium without and with varying amounts of (TFE). The mode that impedance graphs have an around semi-round occurrence illustrated that the dissolution of $\mathrm{Al}$ in $2 \mathrm{M} \mathrm{HCl}$ is influenced by a charge transfer impedance procedure. A little curving has seen indefinite outlines, and this expression has been attributed to inhomogeneity of the Al surface [30] due to surface unpleasantness, impurities, dissimilarity, grain limits, adsorption of inhibitor molecules and arrangement of porous layers. The capacitive loop diameter expanded with the expansion of the amount of TFE and illustrated the 
level of inhibitive impact of the dissolution process. The inductive loop is by and large ascribed to the adsorption of species coming about due to the $\mathrm{Al}$ dissolution and the $\mathrm{H}_{2}$ adsorption [31].

The equivalent circuit observed in Figure 4 was applied to break down the acquired impedance details. The model includes the resistance of destructive solution $\left(\mathrm{R}_{\mathrm{s}}\right)$, the charge transfer resistance $\left(\mathrm{R}_{\mathrm{ct}}\right)$, the inductance $(\mathrm{L})$, the inductive resistance $\left(\mathrm{R}_{\mathrm{L}}\right)$, and the double-layer capacitance $\left(\mathrm{C}_{\mathrm{dl}}\right)$. A great fit with the applied model was gotten with our obtained calculations [32]. At the point when an inductive loop is available, the polarization resistance $\left(\mathrm{R}_{\mathrm{P}}\right)$ can be detected from the next eq. (5):

$$
\mathrm{R}_{\mathrm{P}}=\left(\mathrm{R}_{\mathrm{ct}} \mathrm{X} \mathrm{R}_{\mathrm{L}}\right) /\left(\mathrm{R}_{\mathrm{ct}}+\mathrm{R}_{\mathrm{L}}\right)
$$

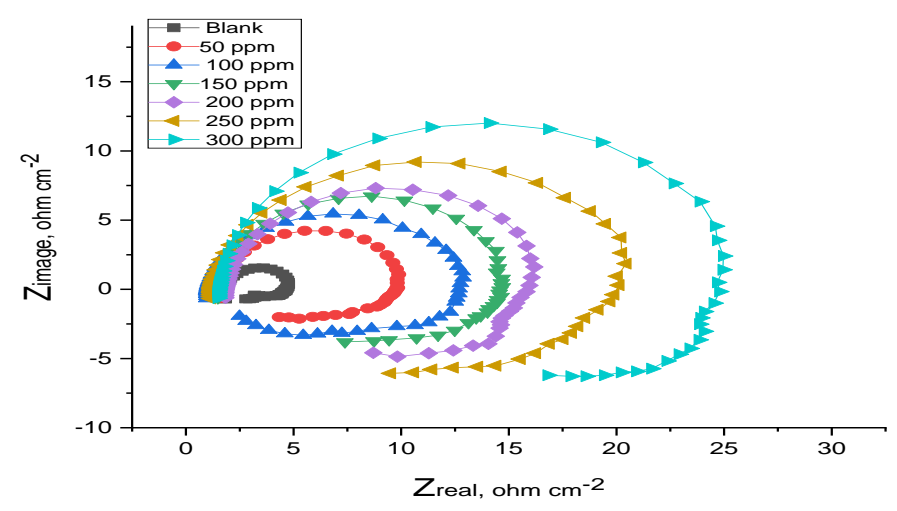

Figure 3. Nyquist graphs of $\mathrm{Al}$ in $2 \mathrm{M} \mathrm{HCl}$ without and with varied amounts of TFE at $25^{\circ} \mathrm{C}$.

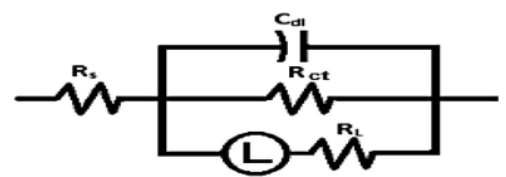

Figure 4. Equivalent loop performed to fit the impedance outcomes.

EIS outcomes from Table 3 demonstrated that the $R_{P}$ values raised and the $C_{d l}$ values diminished with the expansion of TFE concentrations. This is because of the continual exchanging of $\mathrm{H}_{2} \mathrm{O}$ particles by the adsorption of TFE components on the $\mathrm{Al}$ outer surface and lessening the degree of the dissolution response. The large $\mathrm{R}_{\mathrm{P}}$ estimations are ascribed to a small dissolution framework $[33,34]$. The decline in the $\mathrm{C}_{\mathrm{dl}}$ is referred to as the decrease of the local dielectric constant or potentially from the expansion of strength of the electric double layer [35], illustrating that TFE particles impede dissolution by adsorption on the Al outer surface.

Table 3. Electrochemical calculations obtained from EIS for $\mathrm{Al}$ in $2 \mathrm{M} \mathrm{HCl}$ medium in the non-existence and existence of varied amounts of TFE at $25^{\circ} \mathrm{C}$.

\begin{tabular}{|c|c|c|c|c|}
\hline $\begin{array}{l}\text { Conc., } \\
\text { ppm }\end{array}$ & $\begin{array}{c}R_{\mathbf{p}}, \\
\Omega \mathrm{cm}^{2}\end{array}$ & $\begin{array}{c}\mathrm{C}_{\mathrm{dl}}, \\
\mu \mathrm{Fcm}^{-2}\end{array}$ & $\boldsymbol{\theta}$ & $\% \mathrm{IE}$ \\
\hline Blank & 1.44 & 75.67 & ---- & ---- \\
\hline 50 & 5.11 & 42.38 & 0.718 & 71.8 \\
\hline 100 & 6.47 & 38.54 & 0.777 & 77.7 \\
\hline 150 & 7.54 & 33.67 & 0.809 & 80.9 \\
\hline 200 & 9.16 & 27.19 & 0.843 & 84.3 \\
\hline 250 & 11.62 & 23.22 & 0.876 & 87.6 \\
\hline 300 & 12.71 & 18.61 & 0.887 & 88.7 \\
\hline
\end{tabular}




\subsection{Electrochemical frequency modulation (EFM).}

EFM is a non-devastating dissolution procedure which able to readily detect the current dissolution characteristics without prior details on Tafel slopes, and with only a portion of the polarizing signal. The main purposes of EFM system make it a perfect candidate for online dissolution observation [36]. The ideal quality of the EFM is the causality factors that fill in as an inner test on the veracity of the obtained estimations. The CF-2 and CF-3 are detected from the frequency extent of the current responses. Figure 5 illustrated the EFM Intermodulation spectrum (frequency against the current) of $\mathrm{Al}$ in $2 \mathrm{M} \mathrm{HCl}$ medium involving varying amounts of (TFE) [37].
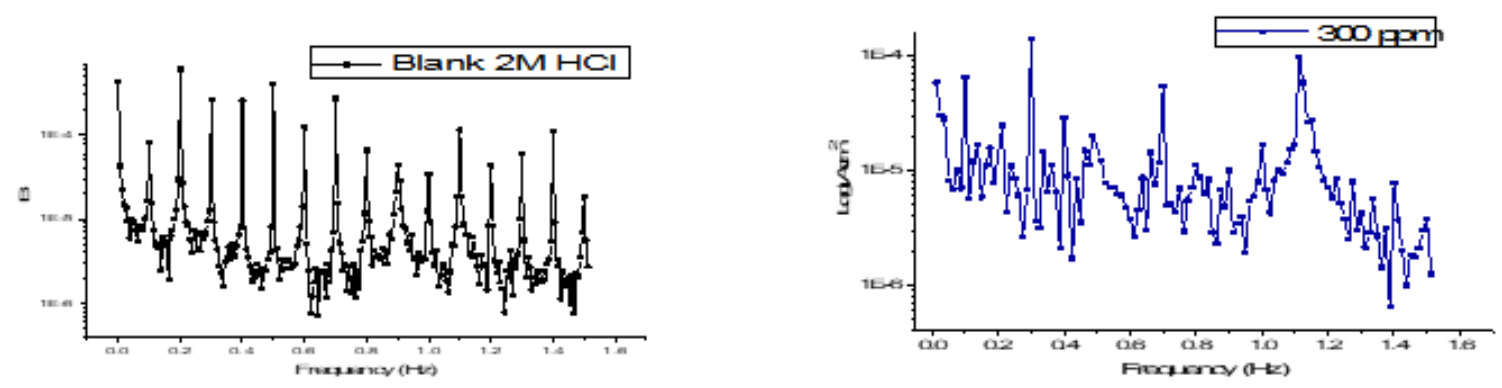

Figure 5. EFM spectra for $\mathrm{Al}$ in $2 \mathrm{M} \mathrm{HCl}$ without and with the existence of $300 \mathrm{ppm}$ of $\mathrm{TFE}$ at $25^{\circ} \mathrm{C}$.

The larger maximum peaks were performed to calculate the dissolution current (icorr), the Tafel slopes ( $\beta_{\mathrm{c}}$ and $\beta_{\mathrm{a}}$ ), and the causality factors (CF-2 and CF-3). All outcomes were listed in Table 4. The outcomes have gotten in Table 4 clearly illustrated that the increase of (TFE) at an offered concentration to the blank medium diminishes the dissolution current, indicating that this extract impeded the dissolution of $\mathrm{Al}$ in $2 \mathrm{M} \mathrm{HCl}$. The causality factors gotten under varied empirical conditions are equal to the theoretical levels (2 and 3), illustrating that the resulted calculations are checked and of perfect form. The inhibition abilities \%IEEFM increased by increasing TFE concentration

\subsection{Gasometry.}

The emitted $\mathrm{H}_{2}$ gas amount obtained from the dissolution procedure can be detected. Estimations gotten by this trial in Figure 6 are appropriate with varied techniques such as electrochemical calculations and mass reduction method. The emitted $\mathrm{H}_{2}$ is dependent on the reaction period, according to eq. (6):

$$
\mathrm{V}_{\mathrm{ml}}=\mathrm{k}_{\text {corr } . \mathrm{t}}
$$

$\mathrm{V}$ is the volume of the $\mathrm{H}_{2}$ emitted in $\mathrm{ml}, \mathrm{t}$ is the time, and $\mathrm{k}_{\mathrm{corr}}$ is dissolution rate at $25 \mathrm{C}^{\circ}$ [38].

The emitted $\mathrm{H}_{2}$ volume was detected every 20 min, \% IE, and $\mathrm{K}_{\text {corr }}$ are computed by eq. (7):

$$
\% \mathrm{IE}=\left(1-\mathrm{K} / \mathrm{K}_{\mathrm{o}}\right) \times 100
$$

$\mathrm{K}$ and $\mathrm{K}_{\mathrm{o}}$ are the $\mathrm{k}_{\text {corr }}$ in existence and non-existence of different doses of TFE, by graphing $\mathrm{V}_{\mathrm{ml}}$ against $\mathrm{t}$ and $\mathrm{K}_{\text {corr }}$ is the slope. Table 5 demonstrated that the dissolution rate diminished, and \%IE increased with increasing of (TFE) amounts. 
Table 4. Electrochemical outcomes got from EFM for $\mathrm{Al}$ in the absence and presence of varying amounts TFE in $2 \mathrm{M} \mathrm{HCl}$ at $25^{\circ} \mathrm{C}$.

\begin{tabular}{l|c|c|c|c|c|c|c|c}
$\begin{array}{c}\text { Conc., } \\
\text { ppm }\end{array}$ & $\begin{array}{c}\mathbf{i}_{\text {icorr, }} \\
\boldsymbol{\mu} \mathbf{A c m}^{-2}\end{array}$ & $\begin{array}{c}\boldsymbol{\beta}_{\mathbf{a},} \\
\mathbf{m V d e c}^{-1}\end{array}$ & $\begin{array}{c}\boldsymbol{\beta}_{\mathbf{c}}, \\
\mathbf{m V d e c}^{-\mathbf{1}}\end{array}$ & $\mathbf{C F - 2}$ & $\mathbf{C F - 3}$ & $\begin{array}{c}\mathbf{C . R}, \\
\mathbf{m p y}\end{array}$ & $\boldsymbol{\theta}$ & $\boldsymbol{\%} \mathbf{I E}$ \\
\hline Blank & 831.4 & 67.4 & 39.1 & 1.85 & 1.68 & 357.0 & ---- & ---- \\
\hline 50 & 193.4 & 42.1 & 30.0 & 2.05 & 3.21 & 83.4 & 0.767 & 76.7 \\
\hline 100 & 162.7 & 38.9 & 28.7 & 2.11 & 3.07 & 70.2 & 0.804 & 80.4 \\
\hline 150 & 143.5 & 33.4 & 25.9 & 2.41 & 2.64 & 61.9 & 0.827 & 82.7 \\
\hline 200 & 111.7 & 25.4 & 22.7 & 2.23 & 2.73 & 48.2 & 0.866 & 86.6 \\
\hline 250 & 100.2 & 22.3 & 20.1 & 2.71 & 2.15 & 43.2 & 0.879 & 87.9 \\
\hline 300 & 91.1 & 20.5 & 18.5 & 2.62 & 2.56 & 39.3 & 0.890 & 89.0
\end{tabular}

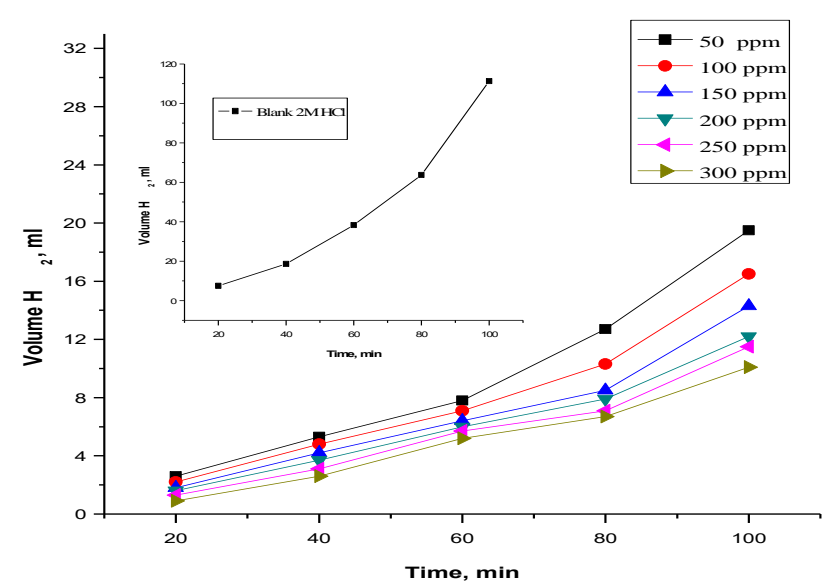

Figure 6. Volumes of emitted $\mathrm{H}_{2}$ gas vs. time for dissolution of $\mathrm{Al}$ in $2 \mathrm{M} \mathrm{HCl}$ at varied amounts of $\mathrm{TFE}$ at $25^{\circ} \mathrm{C}$.

Table 5. IE\% and $\left(\mathrm{k}_{\mathrm{corr}}\right.$ from gasometry for the $\mathrm{Al}$ dissolution in the tested mediums of varying amounts of TFE

\begin{tabular}{c|c|c}
$\begin{array}{c}\text { Conc., } \\
\text { ppm }\end{array}$ & $\begin{array}{c}\text { at } 25^{\circ} \mathrm{C} . \\
\mathbf{k}_{\mathbf{c o r r} \mathbf{1 0}} \mathbf{3}^{-3}, \\
\mathbf{m l} / \mathbf{m i n}\end{array}$ & \% IE \\
\hline Blank & 1200 & ---- \\
\hline $\mathbf{5 0}$ & 206 & 82.8 \\
\hline $\mathbf{1 0 0}$ & 175 & 85.4 \\
\hline $\mathbf{1 5 0}$ & 146.5 & 87.8 \\
\hline $\mathbf{2 0 0}$ & 127 & 89.4 \\
\hline $\mathbf{2 5 0}$ & 122 & 89.8 \\
\hline $\mathbf{3 0 0}$ & 112.5 & 90.6
\end{tabular}

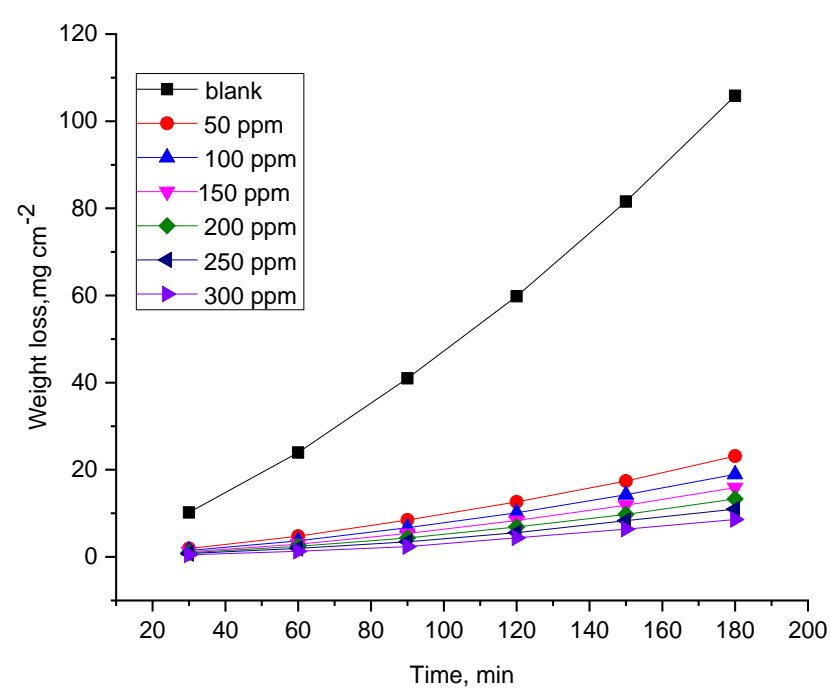

Figure 7. Mass reduction-time graphs for the dissolution of $\mathrm{Al}$ in $2 \mathrm{M} \mathrm{HCl}$ in the absence and presence of varied concentrations of TFE at $25^{\circ} \mathrm{C}$. 


\subsection{Mass reduction tests.}

The dissolution rates of $\mathrm{Al}$ were measured. Figure 7 illustrated the mass reduction versus time without and with varied amounts of TFE at $25 \mathrm{C}^{\circ}$. The uniformity and non-linearity of the graph without TFE demonstrated that the $\mathrm{Al}$ dissolution in $2 \mathrm{M} \mathrm{HCl}$ is a heterogeneous trial involving varied stages. Comparable estimations have been illustrated for Al dissolution in another destructive medium [39]. The surface coverage $(\theta)$ and $\%$ IE that illustrated the mass of $\mathrm{Al}$ outer surface secured by TFE components have appeared in Table 6. \%IE rises with elevating TFE amounts illustrated that more TFE components are adsorbed. This path provides more wide-ranging surface coverage.

Table 6. Dissolution rate and inhibitive ability got from mass reduction technique for $\mathrm{Al}$ in $2 \mathrm{M} \mathrm{HCl}$ solutions in the absence and presence of varying amounts of TFE at $25^{\circ} \mathrm{C}$.

\begin{tabular}{c|c|c|c} 
Conc., ppm & $\begin{array}{c}\text { C.R., } \\
\text { mg.cm } \text {. }^{-2} \mathbf{m i n}^{-1}\end{array}$ & $\boldsymbol{\theta}$ & \% IE \\
\hline blank & 0.455 & $\ldots \ldots \ldots$ & $\ldots \ldots \ldots \ldots$ \\
\hline $\mathbf{5 0}$ & 0.094 & 0.794 & 79.4 \\
\hline $\mathbf{1 0 0}$ & 0.074 & 0.837 & 83.7 \\
\hline $\mathbf{1 5 0}$ & 0.060 & 0.869 & 86.9 \\
\hline $\mathbf{2 0 0}$ & 0.048 & 0.894 & 89.4 \\
\hline $\mathbf{2 5 0}$ & 0.039 & 0.915 & 91.5 \\
\hline $\mathbf{3 0 0}$ & 0.026 & 0.942 & 94.2
\end{tabular}

\subsubsection{Adsorption isotherms.}

Dissolution retardants are appeared to protect $\mathrm{Al}$ dissolution in destructive mediums by adsorbing these components of the extract on the $\mathrm{Al}$ surface where the adsorption of the natural particles occurs due to the binding energy among $\mathrm{H}_{2} \mathrm{O}$ molecules, and the surface is less than that among particles and metal surface [40]. It is explained as a substitution adsorption manner among $\mathrm{H}_{2} \mathrm{O}$ particles, and the natural products exist in the aqueous condition (org aq) [41].

$$
\mathrm{xH}_{2} \mathrm{O} \text { ads }+\mathrm{Org}_{\text {sol }} \leftrightarrow \text { Org ads }+\mathrm{xH}_{2} \mathrm{O}
$$

Where $\mathrm{x}$ is the volume ratio that is the magnitude of $\mathrm{H}_{2} \mathrm{O}$ particles substituted by single organic component, the particles may be physisorbed or chemisorbed on the metal surface, where the physisorbed mechanism hinder metal dissolution by reducing the cathodic response while chemisorbed one hinder the anodic response by decreasing the potential response of the metal at the adsorption locations [42]. It has been realized that the perfect adsorption isotherm is Langmuir that was characterized as following [43]:

$$
\left(\frac{\theta}{1-\theta}\right)=\text { Kads } C
$$

Where $\mathrm{C}$ is the concentration (ppm) of TFE, $\theta$ is the surface coverage area, and $\mathrm{K}_{\mathrm{ads}}$ is the adsorption equilibrium consistent. A graph of $\theta /(1-\theta)$ versus $C$ produced lines, and the slope is referred to $\mathrm{K}_{\mathrm{ads}}$ as observed in Figure 8. All thermodynamic estimations of adsorption were tabulated. The distinguished calculations are the free energy of adsorption $\left(\Delta \mathrm{G}_{\text {ads }}^{\circ}\right)$, the enthalpy $\left(\Delta \mathrm{H}^{\circ}\right.$ ads $)$ and the entropy $\left(\Delta \mathrm{S}^{\circ}\right.$ ads). These values can be computed by varied scientific manners relying upon the rates of $K_{a d s}$ at varied temperatures [44] (Fig. 9). The variation in free energy can be computed from eq. (10):

$$
\mathrm{K}_{\text {ads }}=(1 / 55.5) \exp \left(-\Delta \mathrm{G}^{\circ} \text { ads } / \mathrm{RT}\right)
$$


Where 55.5 is the amount of $\mathrm{H}_{2} \mathrm{O}$ in $\mathrm{mol} \mathrm{l}^{-1}$, $\mathrm{T}$ is the temperature and $\mathrm{R}$ is the universal gas constant. $\left(\Delta \mathrm{H}^{\circ}\right.$ ads $),\left(\Delta \mathrm{S}^{\circ}\right.$ ads $)$ can be computed from eq. $(11 \& 12)$ :

$$
\begin{gathered}
\log \mathrm{K}_{\text {ads }}=\left(\Delta \mathrm{H}_{\text {ads }}^{\circ} / 2.303 \mathrm{RT}\right)+\text { constant } \\
\Delta \mathrm{G}_{\text {ads }}^{\circ}=\Delta \mathrm{H}^{\circ}{ }_{\text {ads }}-\mathrm{T} \Delta \mathrm{S}^{\circ}{ }_{\text {ads }}
\end{gathered}
$$

Table 7 illustrated the resulted thermodynamic calculations and demonstrated that the indication of $\Delta \mathrm{G}_{\text {ads }}^{\circ}$ was negative that illustrated that TFE is adsorbed in spontaneous mode.

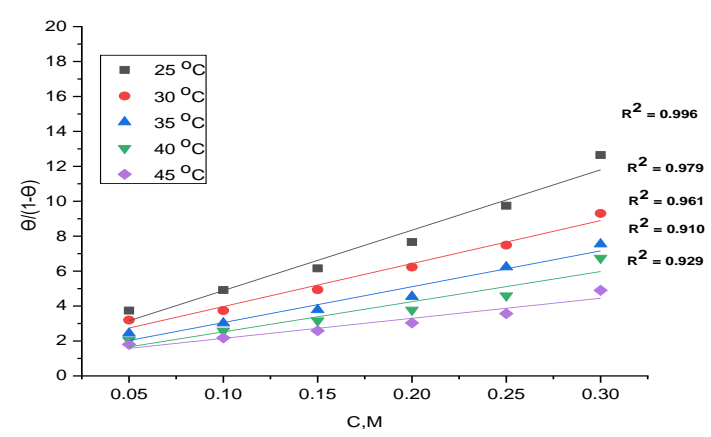

Figure 8. Graph fitting of dissolution outcomes for $\mathrm{Al}$ in $2 \mathrm{M} \mathrm{HCl}$ in presence of varied amounts of TFE to Langmuir isotherm at varied temperatures

Table 7. Thermodynamic estimations for the adsorption of TFE on $\mathrm{Al}$ surface in $2 \mathrm{M} \mathrm{HCl}$ at varied

\begin{tabular}{|c|c|c|c|c|}
\hline $\begin{array}{l}\text { Temperature, } \\
\mathrm{C}^{\mathrm{o}}\end{array}$ & $\begin{array}{l}\mathrm{K}_{\text {ads }} \\
\mathrm{M}^{-1}\end{array}$ & $\begin{array}{l}\mathrm{G}_{\text {ads }}^{\mathrm{o}}, \boldsymbol{- \boldsymbol { \Delta }} \\
\mathrm{KJ} \mathrm{mole}^{-1}\end{array}$ & $\begin{array}{l}-\Delta \mathrm{H}^{\circ} \text { ads } \\
\mathrm{kJ} \mathrm{mol}^{-1}\end{array}$ & $\begin{array}{l}-\Delta \mathrm{S}_{\text {ads }}, \\
\mathrm{J} \mathrm{mol}^{-1} \mathrm{~K}^{-1}\end{array}$ \\
\hline 25 & 34.75 & 18.7 & \multirow{5}{*}{40.5} & 73.2 \\
\hline 30 & 24.62 & 18.2 & & 73.6 \\
\hline 35 & 20.53 & 18.0 & & 73.1 \\
\hline 40 & 17.26 & 17.9 & & 72.2 \\
\hline 45 & 11.48 & 17.1 & & 73.6 \\
\hline
\end{tabular}
temperatures.

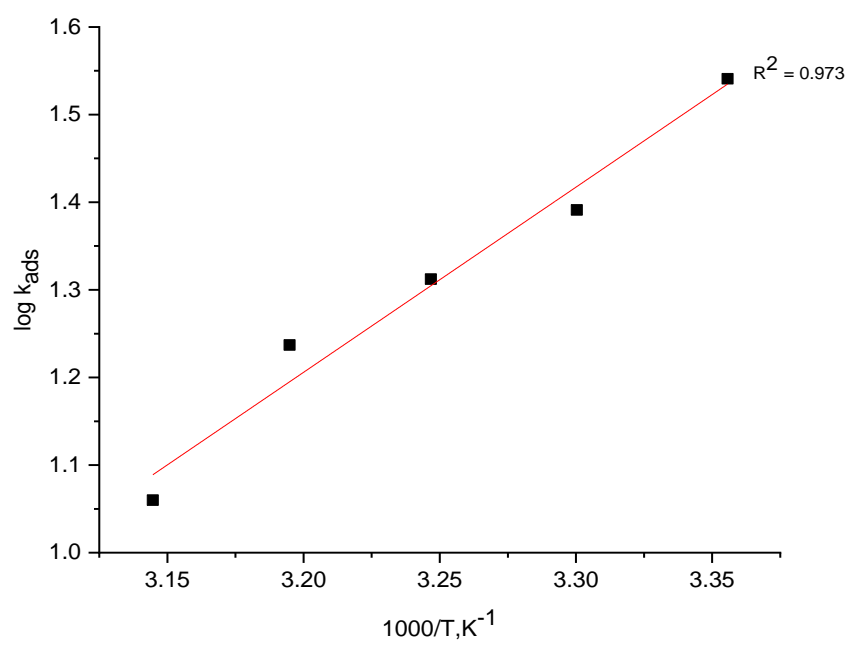

Figure 9. $\log \mathrm{k}_{\text {ads }}$ versus $(1 / \mathrm{T})$ for the dissolution of $\mathrm{Al}$ in $2 \mathrm{M} \mathrm{HCl}$ in the existence of varied concentrations of TFE.

It is observed that the estimations of $\Delta \mathrm{G}^{\circ}$ ads of $40 \mathrm{~kJ} \mathrm{~mol}^{-1}$ and more including charge contribution from the inhibitor particles to the metal surface by coordination bond (chemisorption); but the estimations of $20 \mathrm{~kJ} \mathrm{~mol}^{-1}$ and lower suggested that the electrostatic 
interference among outer metal surface and charged components in the majority of the destructive medium illustrated a physisorption manner $[45,46]$. The computed $\Delta \mathrm{G}^{\circ}$ ads are -20 $\mathrm{kJ} \mathrm{mol}^{-1}$ and lower that ascribed to the electrostatic interference among the charged components and the charged metal (physisorption).

The negative indication of $\Delta \mathrm{H}^{\circ}$ ads illustrated that the adsorption of the inhibitor particles is an exothermic procedure. It is known that an exothermic process is ascribed to either physisorption or chemisorption, but the endothermic procedure is referred to as chemisorption [47]. Generally, enthalpy estimations around $41.9 \mathrm{~kJ} \mathrm{~mol}^{-1}$ indicated physisorption, but these up to $100 \mathrm{~kJ} . \mathrm{mol}^{-1}$ and larger are ascribed to chemisorption. The computed $\Delta \mathrm{H}^{\circ}$ ads are negatively illustrating that TFE might be physisorbed. The $\Delta \mathrm{S}^{\circ}$ ads estimations are negative, which is ascribed to exothermic adsorption procedure and demonstrated that the inhibitor components, moving freely in the electrolyte were adsorbed in an organized manner onto the Al outer surface.

\subsubsection{Thermodynamic activation calculations.}

The activation factors for the dissolution procedure were demonstrated according to Arrhenius eq. (13):

$$
\mathrm{k}_{\mathrm{corr}}=\mathrm{A} \exp \left(\mathrm{E}_{\mathrm{a}}^{*} / \mathrm{RT}\right)
$$

Where $\mathrm{k}_{\text {corr }}$ is the dissolution rate, $\mathrm{R}$ is the universal gas consistent, $\mathrm{E}_{\mathrm{a}}{ }_{\mathrm{a}}$ is the activation dissolution energy, $\mathrm{T}$ represents the temperature, and A refers to the Arrhenius constant. Calculations of $\mathrm{E}_{\mathrm{a}}^{*}$ of $\mathrm{Al}$ dissolution in the existence of varied amounts of TFE were computed from the relation of $\log \left(\mathrm{k}_{\mathrm{corr}}\right)$ against $1 / \mathrm{T}$ graphs, as appeared in Figure 10. The limitation of transition state relation appears in eq. (14):

$$
\mathrm{k}_{\mathrm{corr}}=(\mathrm{RT} / \mathrm{Nh}) \exp \left(\Delta \mathrm{S}^{*} / \mathrm{R}\right) \exp \left(-\Delta \mathrm{H}^{*} / \mathrm{RT}\right)
$$

Where $\mathrm{N}$ is referred to Avogadro's number, $\mathrm{h}$ is ascribed to Planck's parameter, $\Delta \mathrm{S}^{*}$ is the activated entropy, and $\Delta H^{*}$ is referred to the activated enthalpy. A graph of (log kcorr $\left./ \mathrm{T}\right)$ versus $(1 / T)$ established lines as showed in Figure 11 with slopes $\left(\Delta H^{*} / 2.303 R\right)$ and intercepts log $\left(\mathrm{R} / \mathrm{Nh}+\Delta \mathrm{S}^{*} / 2.303 \mathrm{R}\right)$.

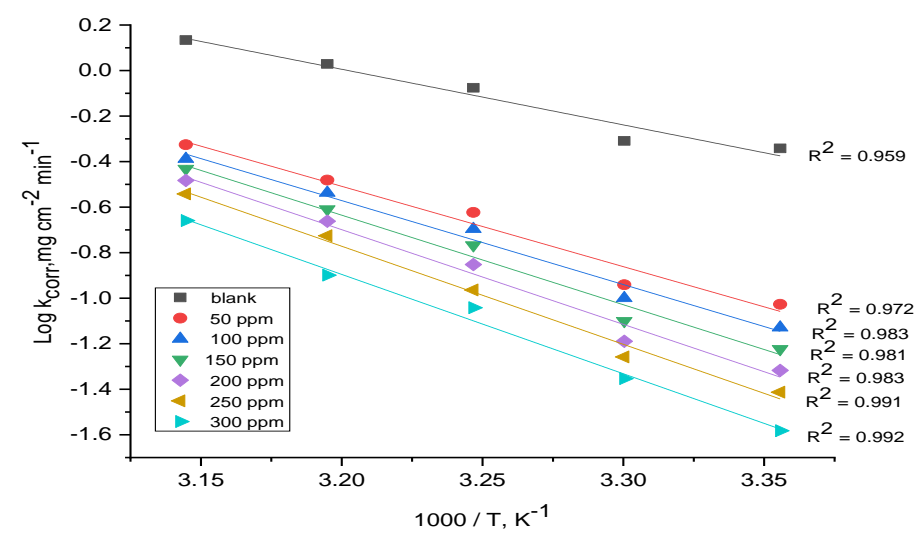

Figure 10. Arrhenius graphs for $\mathrm{Al}$ dissolution rates $\left(\mathrm{k}_{\mathrm{corr}}\right)$ after 90 minutes of immersing in $2 \mathrm{M} \mathrm{HCl}$ in the blank and presence of varying amounts of TFE.

All estimations are put in Table 8. The elevating in $\mathrm{E}^{*}{ }_{\mathrm{a}}$ amounts illustrated that TFE is physisorbed on the $\mathrm{Al}$ outer surface [48]. The positive indications of $\Delta \mathrm{H}^{*}$ demonstrated the 
endothermic nature of the $\mathrm{Al}$ dissolution procedure. The negative $\Delta \mathrm{S}^{*}$ illustrated that in the rate computing stage, the association of unstable coordinated components is higher than the dissociation [49].

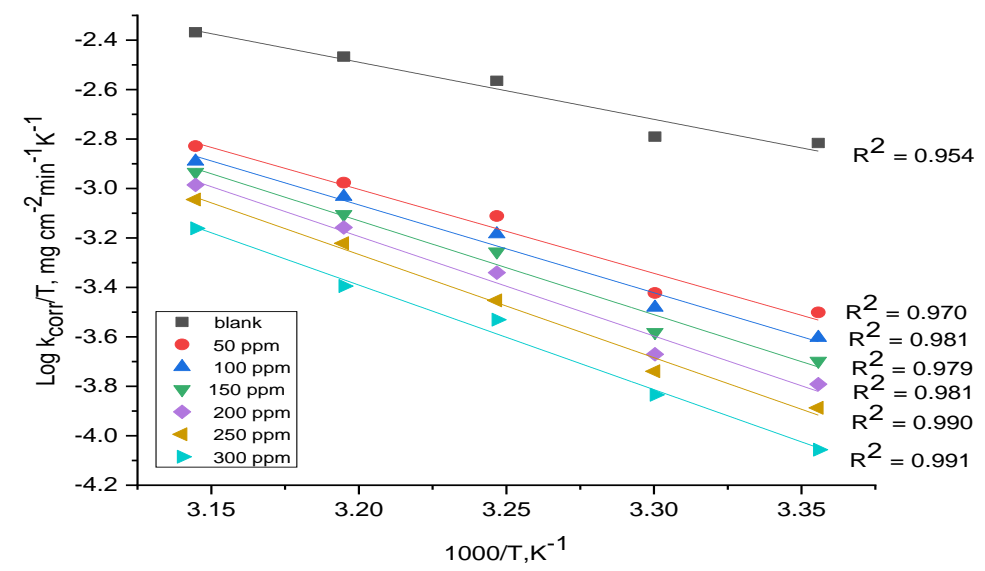

Figure 11. Transition-state for $\mathrm{Al}$ dissolution rates $\left(\mathrm{k}_{\text {corr }}\right)$ in $2 \mathrm{M} \mathrm{HCl}$ in the blank and presence of varied concentrations of TFE.

Table 8. Activation estimations for $\mathrm{Al}$ dissolution in $2 \mathrm{M} \mathrm{HCl}$ in the blank and presence of varied amounts of TFE.

\begin{tabular}{l|l|l|l} 
Concentrations, ppm & \multicolumn{3}{c}{ Activation parameters } \\
\hline & \multicolumn{1}{|c|}{$\begin{array}{c}\mathbf{E}^{*} \mathbf{a}, \\
\mathbf{k J ~ m o l}^{-1}\end{array}$} & $\begin{array}{c}\Delta \mathbf{H}^{*}, \\
\mathbf{k J ~ m o l}^{-1}\end{array}$ & \multicolumn{1}{c}{$\begin{array}{c}-\Delta \mathbf{S}^{*}, \\
\mathbf{~ m o l}^{-1} \mathbf{K}^{-\mathbf{1}}\end{array}$} \\
\hline Blank & 46.6 & 44.3 & 103.4 \\
\hline 50 & 67.6 & 65.0 & 47.0 \\
\hline 100 & 70.6 & 68.0 & 38.5 \\
\hline 150 & 75.3 & 72.7 & 24.7 \\
\hline 200 & 79.7 & 77.1 & 12.0 \\
\hline 250 & 80.5 & 79.9 & 4.3 \\
\hline 300 & 83.5 & 80.9 & 3.4
\end{tabular}

\subsubsection{Impact of Temperature.}

The impact of temperature on the dissolution rate of $\mathrm{Al}$ in $2 \mathrm{M} \mathrm{HCl}$ and varied retardant amounts was examined in the temperature extent (25-45) $\mathrm{C}^{\mathrm{o}}$ utilizing mass reduction procedure. As the temperature raised, the rate of dissolution raised and \%IE of the added retardant diminished, as showed in Table 9.

Table 9. Variation of inhibition protection (\% IE) and surface coverage $(\theta)$ for varying amounts of TFE at varied temperatures at 90 min dipping in the corrosive medium.

\begin{tabular}{|c|c|c|c|c|}
\hline Conc., ppm & Temp., $C^{o}$ & Weight loss, $\mathrm{mg} / \mathrm{cm}^{2}$ & $\boldsymbol{\theta}$ & $\%$ IE \\
\hline \multirow[t]{5}{*}{50} & 25 & 8.45 & 0.794 & 79.4 \\
\hline & 30 & 10.308 & 0.767 & 76.7 \\
\hline & 35 & 21.45 & 0.716 & 71.6 \\
\hline & 40 & 29.725 & 0.691 & 69.1 \\
\hline & 45 & 42.45 & 0.653 & 65.3 \\
\hline \multirow[t]{5}{*}{100} & 25 & 6.683 & 0.837 & 83.7 \\
\hline & 30 & 8.992 & 0.797 & 79.7 \\
\hline & 35 & 18.142 & 0.760 & 76.0 \\
\hline & 40 & 26.108 & 0.729 & 72.9 \\
\hline & 45 & 36.867 & 0.699 & 69.9 \\
\hline \multirow[t]{5}{*}{150} & 25 & 5.383 & 0.869 & 86.9 \\
\hline & 30 & 7.142 & 0.838 & 83.8 \\
\hline & 35 & 15.392 & 0.796 & 79.6 \\
\hline & 40 & 22.158 & 0.770 & 77.0 \\
\hline & 45 & 22.158 & 0.728 & 72.8 \\
\hline
\end{tabular}




\begin{tabular}{|c|c|c|c|c|}
\hline Conc., ppm & Temp., $\mathbf{C}^{\mathbf{o}}$ & Weight loss, $\mathbf{m g} / \mathrm{cm}^{2}$ & $\boldsymbol{\theta}$ & $\%$ IE \\
\hline \multirow[t]{5}{*}{200} & 25 & 33.342 & 0.894 & 89.4 \\
\hline & 30 & 4.333 & 0.868 & 86.8 \\
\hline & 35 & 5.825 & 0.832 & 83.2 \\
\hline & 40 & 12.658 & 0.796 & 79.6 \\
\hline & 45 & 19.592 & 0.758 & 75.8 \\
\hline \multirow[t]{5}{*}{250} & 25 & 29.608 & 0.915 & 91.5 \\
\hline & 30 & 3.475 & 0.888 & 88.8 \\
\hline & 35 & 4.967 & 0.871 & 87.1 \\
\hline & 40 & 16.925 & 0.824 & 82.4 \\
\hline & 45 & 25.867 & 0.789 & 78.9 \\
\hline \multirow[t]{5}{*}{300} & 25 & 2.358 & 0.942 & 94.2 \\
\hline & 30 & 3.992 & 0.910 & 91.0 \\
\hline & 35 & 8.167 & 0.892 & 89.2 \\
\hline & 40 & 11.35 & 0.882 & 88.2 \\
\hline & 45 & 19.725 & 0.839 & 83.9 \\
\hline
\end{tabular}

3.6. X-ray photoelectron spectroscopy (XPS) check.

XPS check affords accurate information about the binding energies of the interference among Tussilago Farfara extract (TFE) and the Al outer surface. The XPS curves of Al 2p, C $1 \mathrm{~s}, \mathrm{Cl} 2 \mathrm{p}, \mathrm{N} 1 \mathrm{~s}$, and $\mathrm{O} 1 \mathrm{~s}$ were got for $\mathrm{Al}$ surface after submersion in $2 \mathrm{M} \mathrm{HCl}$ with the typical concentration of $300 \mathrm{ppm}$ of (TFE) following deconvolution by curvature fitting were observed in Figure 12. The $\mathrm{Al} 2 \mathrm{p}$ spectrum indicated one top at binding energy (BE) of $74.38 \mathrm{eV}$. This top is referred to $\mathrm{Al}_{2} \mathrm{O}_{3}$, as observed in (Fig. 12a). The $\mathrm{C} 1 \mathrm{~s}$ tops demonstrated five tops at 284.51, 286.15, 288.07, 289.14 and $289.93 \mathrm{eV}$ (Fig. 12b). The top at 284.51 can be related to the $\mathrm{C}-\mathrm{C}$ and $\mathrm{C}-\mathrm{H}$ bonds of organic components. Also, the top at $286.15 \mathrm{eV}$ is ascribed to the $\mathrm{C}-\mathrm{OH}$ and $\mathrm{C}-\mathrm{O}-\mathrm{C}$ bonds [50]. The top situated at $288.07 \mathrm{eV}$, which referred to $\mathrm{C}=\mathrm{O}$ demonstrated that (TFE) components had been adsorbed [51]. The tops existed at 289.14 and $289.93 \mathrm{eV}$ are ascribed to $\mathrm{O}-\mathrm{C}=\mathrm{O}$ bond. The $\mathrm{Cl} 2 \mathrm{p}$ is deconvoluted into two tops presented at 198.81eV related to $\mathrm{Cl} 2 \mathrm{p} 3 / 2$ and $202.11 \mathrm{eV}$ ascribed to $\mathrm{Cl} 2 \mathrm{p} 1 / 2$ (Fig. 12c) [52]. The graph of $\mathrm{N}$ 1s illustrated one peak that existed at $399.74 \mathrm{eV}$ that ascribed to $\mathrm{N}$ in organic rings (Figure 12d). The spectra of $\mathrm{O} 1 \mathrm{~s}$ (Fig.12e) is deconvoluted into three tops, the top at $531.28 \mathrm{eV}$ that referred to $\mathrm{Al}_{2} \mathrm{O}_{3}$, the peak at $532.14 \mathrm{eV}$ that ascribed to $\mathrm{C}-\mathrm{O}$ bond [53], while the top existed at $532.22 \mathrm{eV}$ binding energy that related to the C-O-C organic bonds [54]. Lastly, the XPS outcomes illustrated that the defensive layer existed on the $\mathrm{Al}$ outer surface consists of $\mathrm{C}$ and $\mathrm{O}$ atoms in several components.

\subsection{FTIR analysis.}

FTIR spectrum illustrated detailed features such as a high sign to disorder attribution, large affectability and selectivity, accuracy, mechanical integrity, short check period and a small amount of examined material [55]. Figure 13 illustrated the FTIR spectra of pure extract. The broad peak situated at $3332 \mathrm{~cm}^{-1}$ can be ascribed to $(\mathrm{OH})$. The bands at $(2974,2928$ and $2884)^{-1}$ are referred to $\left(\mathrm{CH}_{3}\right)$ and $(\mathrm{C}-\mathrm{H})$ extending, the top at $1654 \mathrm{~cm}^{-1}$ is related to $(\mathrm{C}=\mathrm{C})$, the stretching $-\mathrm{CH}_{3}$ and $-\mathrm{CH}_{2}$ appeared at $1380 \mathrm{~cm}^{-1}$ and $1453 \mathrm{~cm}^{-1}$, the bending $-\mathrm{C}-\mathrm{N}-$ located at $1046 \mathrm{~cm}^{-1}$ and the bending $=\mathrm{C}-\mathrm{H}$ and $=\mathrm{CH}_{2}$ existed at $880 \mathrm{~cm}^{-1}$. There are disappearing and shifting in the frequencies. The stretch of $(\mathrm{O}-\mathrm{H})$ at $3332 \mathrm{~cm}^{-1}$ became at $3347 \mathrm{~cm}^{-1}$, the $\mathrm{C}=\mathrm{C}$ bond at $1654 \mathrm{~cm}^{-1}$ was shifted to $1636 \mathrm{~cm}^{-1}$. All outcomes illustrated the interference among the TFE molecules and $\mathrm{Al}$ outer surface through the resulted functional groups. The disappeared groups demonstrated the adsorption manner of TFE on the Al outer surface [56]. These groups have coordinated with $\mathrm{Al}^{3+}$ causing the consistence of $\mathrm{Al}^{3+}-\mathrm{TFE}$ complex, which increases the inhibitive impact of $\mathrm{Al}$ dissolution in corrosive mediums. 

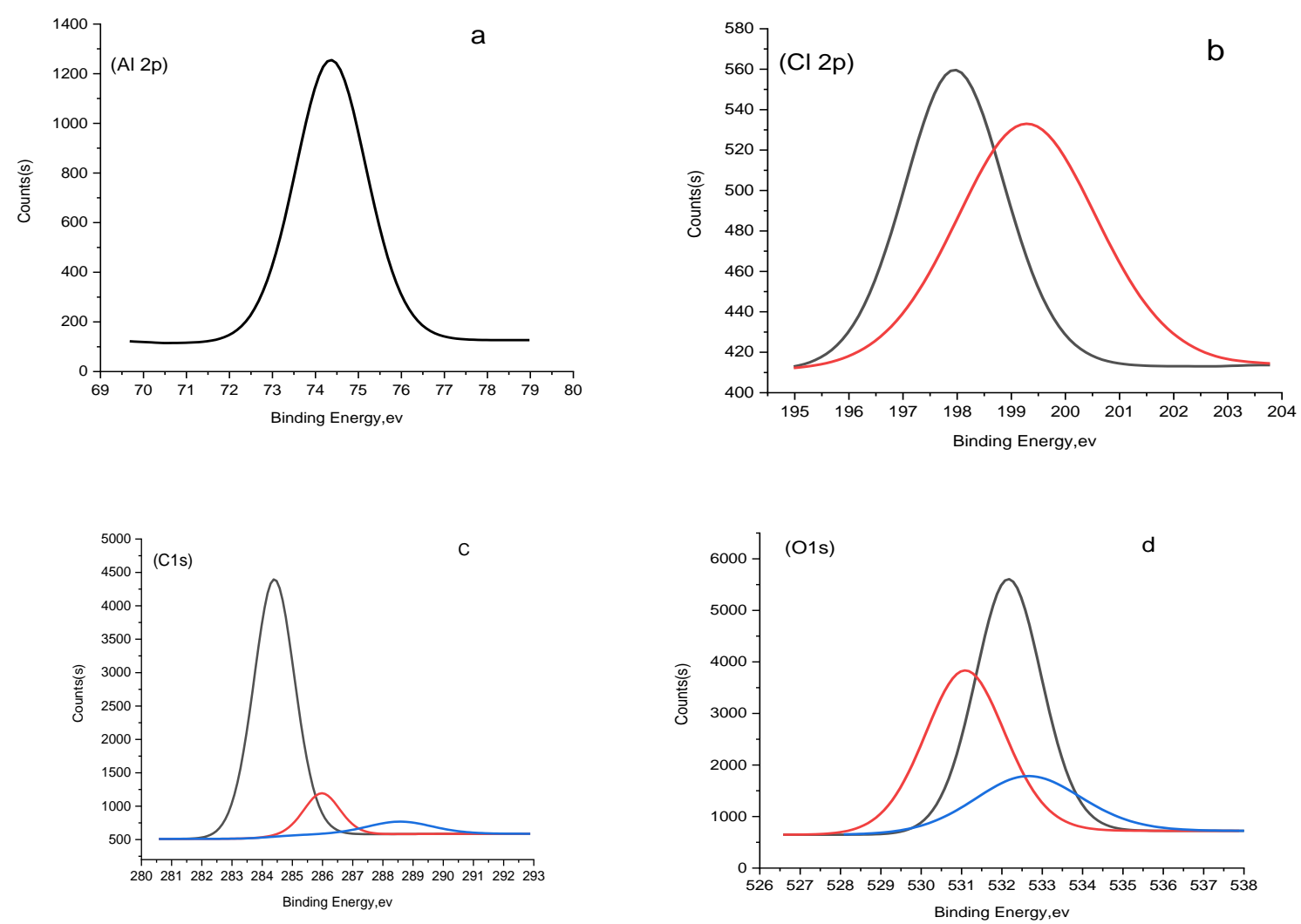

Figure 12. XPS micrographs of (a) $\mathrm{Al} \mathrm{2p}$, (b) $\mathrm{C} \mathrm{1s,} \mathrm{(c)} \mathrm{Cl} 2 \mathrm{p}$, (d) $\mathrm{N}$ 1s and (e) $\mathrm{O}$ 1s spectra for $\mathrm{Al}$ in $2 \mathrm{M} \mathrm{HCl}$.

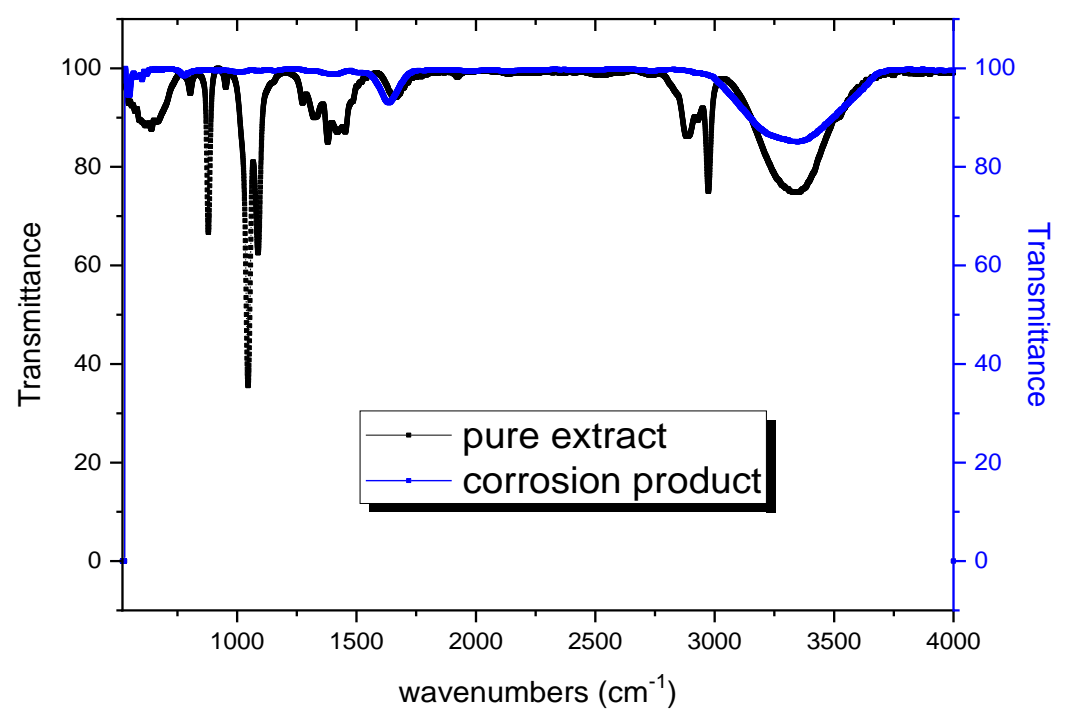

Figure 13. IR spectrum of pure extract and dissolution products of $\mathrm{Al}$ after the mass reduction procedure in existence of $300 \mathrm{ppm}$ of TFE at $25^{\circ} \mathrm{C}$.

\subsection{Atomic force microscope (AFM) check.}

AFM provides detailed photos for outer surface morphology with high precision, able to compute the coarseness of the checked surface. The 3D AFM photos for pure Al outer surface and $\mathrm{Al}$ in $2 \mathrm{M} \mathrm{HCl}$ in the non-existence and existence of (TFE) are observed in Figure 14. 
The image of the $\mathrm{Al}$ outer surface in $2 \mathrm{M} \mathrm{HCl}$ has more coarseness $(381.1 \mathrm{~nm})$ than the pure aluminum foil $(15.6 \mathrm{~nm})$, which illustrated that the $\mathrm{Al}$ foil is corroded by the destructive medium. The resulted coarseness of inhibited Al is lowered till reach $(129.1 \mathrm{~nm})$. This is because of the formation of a compacted adsorbed form on the outer surface, thereby hindering the dissolution of $\mathrm{Al}$.

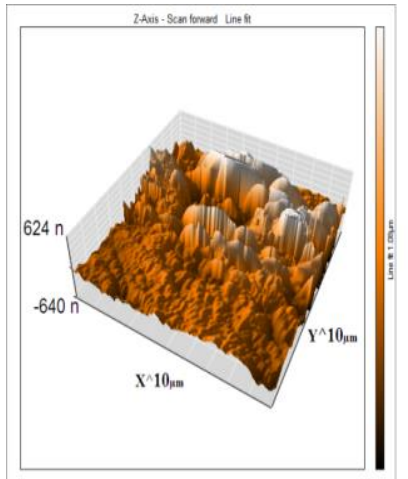

A

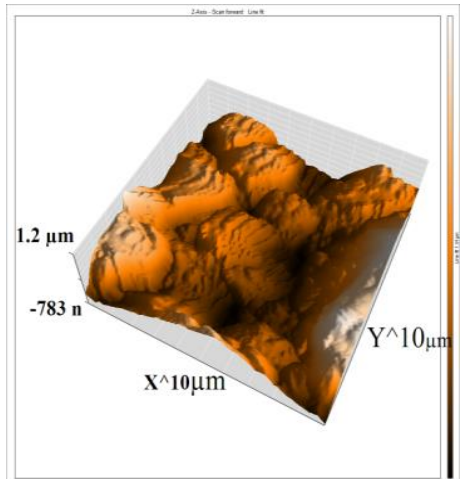

B

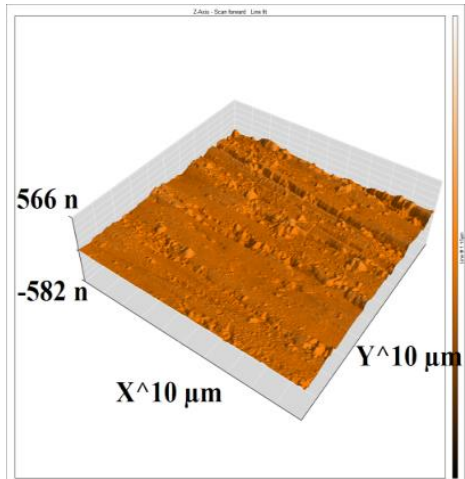

C

Figure 14. 3D AFM of the surface of: A) pure $\mathrm{Al}$ outer surface; $\mathrm{B}$ ) $\mathrm{Al}$ submerged in $2 \mathrm{M} \mathrm{HCl}$; ) $\mathrm{Al}$ submerged in $2 \mathrm{M} \mathrm{HCl}$, including $300 \mathrm{ppm}$ of TFE.

\subsection{Inhibitive Mechanism.}

Metal dissolution occurs by two main responses: oxidation reaction and $\mathrm{H}_{2}$ emission. Inhibitive manner of $\mathrm{Al}$ in the destructive medium is explained due to an adsorption mechanism of the inhibitor components onto the Al surface. The organic components that exist in the extract hindered metal dissolution, most likely by reducing both responses. There are several variables influencing the inhibitive efficiency of the inhibitor as metal kind, molecular structure, destructive medium, the electronic construction, adsorption locations, and substance features, and manner of interference by the accompanying relationships: $\mathrm{Cl}^{-}$ions are adsorbed on the Al positively charged surface converted it to negative. The protonated components of TFE were adsorbed on the negative surface. The resulted outcomes illustrated that the adsorption of these organic components of TFE happened, causing diminishing the dissolution response. The adsorption happens through the anodic sites that occurred through $\pi$-electrons of aromatic rings in TFE extract. XPS check demonstrated that the particles present in TFE were adsorbed on the Al surface, confirming its inhibitive ability [57].

\section{Conclusions}

The outcomes gotten from all procedures illustrated that the inhibitive impact rises with elevating the Tussilago Farfara extract amounts and reduced with elevating the temperature from 25 to $45 \mathrm{C}^{\mathrm{o}}$ (physical adsorption) increasing the dose of Tussilago Farfara extract, reducing the capacity of double-layer $\left(\mathrm{C}_{\mathrm{dl}}\right)$ and elevating the polarization resistance $\left(\mathrm{R}_{\mathrm{p}}\right)$. The adsorption of plant extract components on the Al outer surface is referred to as Langmuir isotherm. Tafel polarization outcomes illustrated that Tussilago Farfara extract appears as an inhibitor of mixed type. The inhibitive proficiencies computed by MR, HE, TP, EIS and EFM procedures are in agreeable estimation. AFM graphs illustrated that TFE is adsorbed on the Al surface, forming a defensive layer. FTIR check of TFE and dissolution product demonstrated the functional groups that have coordinated with $\mathrm{Al}^{3+}$. The XPS technique confirmed the formation of a protective film of TFE on the $\mathrm{Al}$ surface. 


\title{
Funding
}

This research received no external funding.

\section{Acknowledgments}

\begin{abstract}
All our gratitude to the anonymous referees for their careful reading of the manuscript and valuable comments which helped in shaping this paper to the present form. We thank all laboratory staff of corrosion chemistry from the University of Mansoura (Egypt) for their kind cooperation.
\end{abstract}

\section{Conflicts of Interest}

The authors declare no conflict of interest.

\section{References}

1. Chirkunov, A.A.; Chugunov, D.O.; Red'kina, G.V.; Kuznetsov, Y.I. The Influence of Steel Surface Modifying with Zinc Complexes of Phosphonic Acids on the Efficiency of Its Passivation by Organic Inhibitors. Russian Journal of Electrochemistry 2019, 55, 115-121, https://doi.org/10.1134/S1023193519010026.

2. Marzorati, S.; Verotta, L.; Trasatti, P.S. Green Corrosion Inhibitors from Natural Sources and Biomass Wastes. Molecules 2019, 24, https://doi.org/10.3390/molecules24010048.

3. Harvey, T.J.; Walsh, F.C.; Nahlé, A.H. A review of inhibitors for the corrosion of transition metals in aqueous acids. Journal of Molecular Liquids 2018, 266, 160-175, https://doi.org/10.1016/j.molliq.2018.06.014.

4. B.P, C.; Rao, P. Pullulan as a potent green inhibitor for corrosion mitigation of aluminum composite: Electrochemical and surface studies. International Journal of Biological Macromolecules 2018, 112, 461472, https://doi.org/10.1016/j.ijbiomac.2018.01.218.

5. Keyikoglu, R.; Can, O.T.; Aygun, A.; Tek, A. Comparison of the effects of various supporting electrolytes on the treatment of a dye solution by electrocoagulation process. Colloid and Interface Science Communications 2019, 33, https://doi.org/10.1016/j.colcom.2019.100210.

6. Zhang, G.; Zhou, L.; Li, F.; Xia, S.; Yu, L. Experimental and theoretical investigation on the self-assembling inhibition mechanism of dithioamide derivatives on mild steel. Journal of Molecular Structure 2020, 1202, https://doi.org/10.1016/j.molstruc.2019.127286.

7. Nwanonenyi, S.C.; Obasi, H.C.; Oguzie, E.E.; Chukwujike, I.C.; Anyiam, C.K. Inhibition and Adsorption of Polyvinyl Acetate (PVAc) on the Corrosion of Aluminium in Sulphuric and Hydrochloric Acid Environment. Journal of Bio- and Tribo-Corrosion 2017, 3, https://doi.org/10.1007/s40735-017-0114-z.

8. Hassan, R.M.; Ibrahim, S.M.; Salman, S.A.; Takagi, H.D. A Promising Water-Soluble Synthetic Polymer of High Efficiency and Low Cost as Inhibitor for Inhibition of Metals Corrosion: Inhibition of Magnesium Corrosion by Poly (Ethylene Glycol) in Acidic Media. Journal of Bio- and Tribo-Corrosion 2019, 5, https://doi.org/10.1007/s40735-019-0292-y.

9. Liu, Z.; Tang, Y.; Liao, N.; Yang, P. Study on interfacial interaction between Si and ZnO. Ceramics International 2019, 45, 21894-21899, https://doi.org/10.1016/j.ceramint.2019.07.200.

10. Wysocka, J.; Krakowiak, S.; Ryl, J. Evaluation of citric acid corrosion inhibition efficiency and passivation kinetics for aluminium alloys in alkaline media by means of dynamic impedance monitoring. Electrochimica Acta 2017, 258, 1463-1475, https://doi.org/10.1016/j.electacta.2017.12.017.

11. Ramakrishnan, K.; Karthikeyan, S.; Rajagopal, D. Performance evaluation of novel thioctic acid conjugate as green corrosion inhibitor of L80 carbon steels in down pipes used in Khuff gas environment. Materials Research Express 2019, 6.

12. Ryl, J.; Brodowski, M.; Kowalski, M.; Lipinska, W.; Niedzialkowski, P.; Wysocka, J. Corrosion Inhibition Mechanism and Efficiency Differentiation of Dihydroxybenzene Isomers Towards Aluminum Alloy 5754 in Alkaline Media. Materials 2019, 12, https://doi.org/10.3390/ma12193067.

13. Verma, C.; Ebenso, E.E.; Bahadur, I.; Quraishi, M.A. An overview on plant extracts as environmental sustainable and green corrosion inhibitors for metals and alloys in aggressive corrosive media. Journal of Molecular Liquids 2018, 266, 577-590, https://doi.org/10.1016/j.molliq.2018.06.110.

14. Mahmmod, A.A.; Kazarinov, I.A.; Khadom, A.A.; Mahood, H.B. Experimental and Theoretical Studies of Mild Steel Corrosion Inhibition in Phosphoric Acid Using Tetrazoles Derivatives. Journal of Bio- and TriboCorrosion 2018, 4, https://doi.org/10.1007/s40735-018-0171-y. 
15. Benarioua, M.; Mihi, A.; Bouzeghaia, N.; Naoun, M. Mild steel corrosion inhibition by Parsley (Petroselium Sativum) extract in acidic media. Egyptian Journal of Petroleum 2019, 28, 155-159, https://doi.org/10.1016/j.ejpe.2019.01.001.

16. Grudić, V.; Martinez, S.; Knežević, B.; Bošković, I. Corrosion inhibition of steel in a sodium chloride solution by natural honey. Materials Testing 2019, 61, 881-884, https://doi.org/10.3139/120.111398.

17. Xu, B.; Chen, C.; Ma, E.; Wei, Z.; Li, X. Preparation of SiO2/polymer co-coated colored aluminum pigments with excellent corrosion resistance and UV protection and their application in fabrics. Composite Interfaces 2020, https://doi.org/10.1080/09276440.2020.1730659.

18. Reena Kumari, P.D.; Kumari, D. Experimental and Theoretical Evaluation of Rutin as Eco-Friendly Corrosion Inhibitor for Aluminum 6063 Alloy in Acidic Medium. Journal of Failure Analysis and Prevention 2018, 18, 856-867, https://doi.org/10.1007/s11668-018-0473-x.

19. Mariami, T.A.; Antoko, B.; Soim, S. Analisis Laju Korosi dan Lifetime Pipa ASTM A105 dengan Perbandingan Inhibitor $\mathrm{NaNO} 2$ dan $\mathrm{Na} 2 \mathrm{CrO} 4$. Conference on Piping Engineering and Its Application 2019, 4.

20. Noor, E.A.; Al-Moubaraki, A.H.; Al-Ghamdi, A.A. Continuous Studies on Using Camel's Urine as Nontoxic Corrosion Inhibitor-Corrosion Inhibition of Al-Cu Alloy in Alkaline Solutions. Arabian Journal for Science and Engineering 2019, 44, 237-250, https://doi.org/10.1007/s13369-018-3489-3.

21. Usman, B.; Ibrahim, M. Evaluation of corrosion behaviour of aluminum in different environment. 2019, 11, 88-92, https://doi.org/10.4314/bajopas.v11i1.15S.

22. Arumugam, P.; Subbiah, S.; Kannusamy, K. Albizia lebbeck seed extract as effective corrosion inhibitor for Mild steel in acid medium. Biointerface Res. Appl. Chem 2013, 3, 498-506.

23. Arumugam, P.; Subbiah, S.; Kalirajan, K. Corrosion control of mild steel in 1.0N Hydrochloric acid medium using Pyrus pyrifolia fruit peel extract. Biointerface Res. Appl. Chem. 2014, 4, 685-693.

24. Muravnik, L.E.; Kostina, O.V.; Shavarda, A.L. Glandular trichomes of Tussilago Farfara (Senecioneae, Asteraceae). Planta 2016, 244, 737-752, https://doi.org/10.1007/s00425-016-2539-x.

25. Sile, I.; Romane, E.; Reinsone, S.; Maurina, B.; Tirzite, D.; Dambrova, M. Medicinal plants and their uses recorded in the Archives of Latvian Folklore from the 19th century. Journal of Ethnopharmacology 2020, 249, https://doi.org/10.1016/j.jep.2019.112378.

26. Shalabi, K.; Abdallah, Y.M.; Fouda, A.S. Corrosion inhibition of aluminum in $0.5 \mathrm{M} \mathrm{HCl}$ solutions containing phenyl sulfonylacetophenoneazo derivatives. Research on Chemical Intermediates 2015, 41, 4687-4711, https://doi.org/10.1007/s11164-014-1561-5.

27. Norani, M.; Ebadi, M.-T.; Ayyari, M. Volatile constituents and antioxidant capacity of seven Tussilago farfara L. populations in Iran. Scientia Horticulturae 2019, 257, https://doi.org/10.1016/j.scienta.2019.108635.

28. Salc1, A.; Solmaz, R. Fabrication of rhodanine self-assembled monolayer thin films on copper: Solvent optimization and corrosion inhibition studies. Progress in Organic Coatings 2018, 125, 516-524, https://doi.org/10.1016/j.porgcoat.2018.09.020.

29. Palumbo, G.; Górny, M.; Banaś, J. Corrosion Inhibition of Pipeline Carbon Steel (N80) in CO2-Saturated Chloride $(0.5 \mathrm{M}$ of $\mathrm{KCl})$ Solution Using Gum Arabic as a Possible Environmentally Friendly Corrosion Inhibitor for Shale Gas Industry. Journal of Materials Engineering and Performance 2019, 28, 6458-6470, https://doi.org/10.1007/s11665-019-04379-3.

30. Zhan, X.; Tang, J.; Li, H.; Liang, X.; Lu, Y.; Che, Y.; Tu, W.; Zhang, Y. Effects of non-isothermal aging on mechanical properties, corrosion behavior and microstructures of Al-Cu-Mg-Si alloy. Journal of Alloys and Compounds 2020, 819, https://doi.org/10.1016/j.jallcom.2019.152960.

31. Soltani, N.; Tavakkoli, N.; Attaran, A.; Karimi, B.; Khayatkashani, M. Inhibitory effect of Pistacia khinjuk aerial part extract for carbon steel corrosion in sulfuric acid and hydrochloric acid solutions. Chemical Papers 2020, 74, 1799-1815, https://doi.org/10.1007/s11696-019-01026-y.

32. Morales, A.; Piamba, O.; Olaya, J. The Corrosion Resistance of Aluminum-Bronze Coatings as a Function of Gas Pressure Used in the Thermal Spraying Process. Coatings 2019, 9, https://doi.org/10.3390/coatings9080507.

33. Danaee, I.; Nikparsa, P. Electrochemical Frequency Modulation, Electrochemical Noise, and Atomic Force Microscopy Studies on Corrosion Inhibition Behavior of Benzothiazolone for Steel API X100 in $10 \% \mathrm{HCl}$ Solution. Journal of Materials Engineering and Performance 2019, 28, 5088-5103, https://doi.org/10.1007/s11665-019-04272-z.

34. Corrales Luna, M.; Le Manh, T.; Cabrera Sierra, R.; Medina Flores, J.V.; Lartundo Rojas, L.; Arce Estrada, E.M. Study of corrosion behavior of API 5L X52 steel in sulfuric acid in the presence of ionic liquid 1-ethyl 3-methylimidazolium thiocyanate as corrosion inhibitor. Journal of Molecular Liquids 2019, 289, https://doi.org/10.1016/j.molliq.2019.111106.

35. Fouda, A.S.; Shalabi, K.; Shaaban, M.S. Synergistic Effect of Potassium Iodide on Corrosion Inhibition of Carbon Steel by Achillea santolina Extract in Hydrochloric Acid Solution. Journal of Bio- and TriboCorrosion 2019, 5, https://doi.org/10.1007/s40735-019-0260-6. 
36. Fouda, A.S.; Abdel Haleem, E. Berry Leaves Extract as Green Effective Corrosion Inhibitor for Cu in Nitric Acid Solutions. Surface Engineering and Applied Electrochemistry 2018, 54, 498-507, https://doi.org/10.3103/S1068375518050034.

37. Singh, P.; Chauhan, D.S.; Chauhan, S.S.; Singh, G.; Quraishi, M.A. Bioinspired synergistic formulation from dihydropyrimdinones and iodide ions for corrosion inhibition of carbon steel in sulphuric acid. Journal of Molecular Liquids 2020, 298, https://doi.org/10.1016/j.molliq.2019.112051.

38. Li, X.; Deng, S.; Lin, T.; Xie, X.; Xu, X. Inhibition action of triazolyl blue tetrazolium bromide on cold rolled steel corrosion in three chlorinated acetic acids. Journal of Molecular Liquids 2019, 274, 77-89, https://doi.org/10.1016/j.molliq.2018.10.066.

39. Dahmane, M.; Rahmoune, A. Extraction étude de l'activité inhibitrice de la corrosion de l'acier XC 48 des alcoloides extraites à partir de lespèce Peganum Harmala LNigella Sativa L. Univ Blida 2017.

40. Fouda, A.S.; Migahed, M.A.; Atia, A.A.; Mousa, I.M. Corrosion Inhibition and Adsorption Behavior of Some Cationic Surfactants on Carbon Steel in Hydrochloric Acid Solution. Journal of Bio- and TriboCorrosion 2016, 2, https://doi.org/10.1007/s40735-016-0052-1.

41. Njoku, C.N.; Bai, W.; Arukalam, I.O.; Yang, L.; Hou, B.; Njoku, D.I.; Li, Y. Epoxy-based smart coating with self-repairing polyurea-formaldehyde microcapsules for anticorrosion protection of aluminum alloy AA2024. Journal of Coatings Technology and Research 2020, 17, 797-813, https://doi.org/10.1007/s11998020-00334-3.

42. Attia, A.; Abdel-Fatah, H.T.M. Triton X-100 as a Non-Ionic Surfactant for Corrosion Inhibition of Mild Steel During Acid Cleaning. Metals and Materials International 2019, https://doi.org/10.1007/s12540-01900533-7.

43. Liu, Y.; Guo, Y.; Wu, W.; Xiong, Y.; Sun, C.; Yuan, L.; Li, M. A Machine Learning-Based QSAR Model for Benzimidazole Derivatives as Corrosion Inhibitors by Incorporating Comprehensive Feature Selection. Interdisciplinary Sciences: Computational Life Sciences 2019, 11, 738-747, https://doi.org/10.1007/s12539019-00346-7.

44. Brindha, T.; Parimalagandhi, K.; Mallika, J. Thermodynamic and Electrochemical Analysis of Synergistic Corrosion Inhibition Performance of Natural Polysaccharides with Metal Halides on Mild Steel in Hydrochloric Acid Solution. Journal of Bio- and Tribo-Corrosion 2019, 6, https://doi.org/10.1007/s40735019-0296-7.

45. Pourfarzad, H.; Shabani-Nooshabadi, M.; Ganjali, M.R.; Olia, M.H. Inhibition of acid corrosion of glass ampoule in $\mathrm{Pb} / \mathrm{HBF} 4 / \mathrm{PbO} 2$ reserve batteries using nanobis[3-(trimethoxysilyl)propyl]amine. Journal of Molecular Liquids 2020, 302, https://doi.org/10.1016/j.molliq.2020.112578.

46. Ilham, E.; Boutouil, A.; Ben El Ayouchia, H.; Laamari, M.R.; El Haddad, M.; Anane, H.; Salah-Eddine, S. Anti-Corrosive Properties of (1-benzyl-1H-1,2,3-triazol-4-yl) Methanol on Mild Steel Corrosion in Hydrochloric Acid Solution: Experimental and Theoretical Evidences. Protection of Metals and Physical Chemistry of Surfaces 2019, 55, 166-178, https://doi.org/10.1134/S2070205119010118.

47. Fergachi, O.; Benhiba, F.; Rbaa, M.; Ouakki, M.; Galai, M.; Touir, R.; Lakhrissi, B.; Oudda, H.; Touhami, M.E. Corrosion Inhibition of Ordinary Steel in $5.0 \mathrm{M} \mathrm{HCl}$ Medium by Benzimidazole Derivatives: Electrochemical, UV-Visible Spectrometry, and DFT Calculations. Journal of Bio- and Tribo-Corrosion 2019, 5, https://doi.org/10.1007/s40735-018-0215-3.

48. Fouda, A.; Mohamed, A.E.; Khalid, M.A. Trigonella stellate extract as corrosion inhibitor for copper in $1 \mathrm{M}$ nitric acid solution. 2016, 8, 86-98.

49. Chevalier, M.; Robert, F.; Amusant, N.; Traisnel, M.; Roos, C.; Lebrini, M. Enhanced corrosion resistance of mild steel in $1 \mathrm{M}$ hydrochloric acid solution by alkaloids extract from Aniba rosaeodora plant: Electrochemical, phytochemical and XPS studies. Electrochimica Acta 2014, 131, 96-105, https://doi.org/10.1016/j.electacta.2013.12.023.

50. Yadav, M.; Kumar, S.; Sinha, R.R.; Bahadur, I.; Ebenso, E.E. New pyrimidine derivatives as efficient organic inhibitors on mild steel corrosion in acidic medium: Electrochemical, SEM, EDX, AFM and DFT studies. Journal of Molecular Liquids 2015, 211, 135-145, https://doi.org/10.1016/j.molliq.2015.06.063.

51. Zhang, L.; He, Y.; Zhou, Y.; Yang, R.; Yang, Q.; Qing, D.; Niu, Q. A novel imidazoline derivative as corrosion inhibitor for P110 carbon steel in hydrochloric acid environment. Petroleum 2015, 1, 237-243, https://doi.org/10.1016/j.petlm.2015.10.007.

52. Weiss, T.; Warneke, J.; Zielasek, V.; Swiderek, P.; Bäumer, M. XPS study of thermal and electron-induced decomposition of $\mathrm{Ni}$ and $\mathrm{Co}$ acetylacetonate thin films for metal deposition. Journal of Vacuum Science \& Technology A 2016, 34, https://doi.org/10.1116/1.4953469.

53. Fouda, A.S.; Abdel Nazeer, A.; El behairy, W.T. Assessment of Begonia Extract as New Eco-friendly Inhibitor for Low-Carbon-Steel Corrosion in Acidic Environment. Journal of Bio- and Tribo-Corrosion 2017, 4, https://doi.org/10.1007/s40735-017-0122-z.

54. Fouda, A.S.; Abdel Aal, A.; Abdel Haleem, E. Calotropis Procera Extract (CPE) as corrosion inhibitor for Copper in Nitric Acid Medium. Bulletin faculty of science Zagazig university 2017, 39, https://bfszu.journals.ekb.eg/article_31051.html. 
55. Boumhara, K.; Harhar, H.; Tabyaoui, M.; Bellaouchou, A.; Guenbour, A.; Zarrouk, A. Corrosion Inhibition of Mild Steel in 0.5 M H2SO4 Solution by Artemisia herba-alba Oil. Journal of Bio- and Tribo-Corrosion 2018, 5, https://doi.org/10.1007/s40735-018-0202-8.

56. Devi, P.N.; Sathiyabama, J.; Rajendran, S. Electrochemical Characterization of Catechol-Dimethylamine Adduct at Different $\mathrm{pH}$ Values. Int. J. Corros. Scale Inhib. 2017, 186, http://dx.doi.org/10.4152/pea.201901051.

57. Habibiyan, A.; Ramezanzadeh, B.; Mahdavian, M.; Kasaeian, M. Facile size and chemistry-controlled synthesis of mussel-inspired bio-polymers based on Polydopamine Nanospheres: Application as eco-friendly corrosion inhibitors for mild steel against aqueous acidic solution. Journal of Molecular Liquids 2020, https://doi.org/10.1016/j.molliq.2019.111974. 